\title{
Application of moringa leaf extract improves growth and yield of Tomato (Solanum lycopersicum) and Indian Spinach (Basella alba)
}

\author{
Tahsina Sharmin Hoque ${ }^{1}$, Md. Anwarul Abedin ${ }^{1}$, Mohammad Golam Kibria ${ }^{1}$, Israt Jahan ${ }^{1}$ \& Mohammad Anwar Hossain ${ }^{2 *}$ \\ ${ }^{1}$ Department of Soil Science, Bangladesh Agricultural University, Mymensingh 2202, Bangladesh \\ ${ }^{2}$ Department of Genetics and Plant Breeding, Bangladesh Agricultural University, Mymensingh 2202, Bangladesh \\ ^Email: anwargpb@bau.edu.bd
}

\section{OPEN ACCESS}

\section{ARTICLE HISTORY}

Received: 25 June 2021

Accepted: 14 October 2021

Available online

Version 1.0 (Early Access): 15 December 2021 Version 2.0:01 January 2022

\section{Check for updates}

\section{Additional information}

Peer review: Publisher thanks Sectional Editor and the other anonymous reviewers for their contribution to the peer review of this work.

Reprints \& permissions information is available at https://horizonepublishing.com/ journals/index.php/PST/open_access_policy

Publisher's Note: Horizon e-Publishing Group remains neutral with regard to jurisdictional claims in published maps and institutional affiliations.

Indexing: Plant Science Today, published by Horizon e-Publishing Group, is covered by Scopus, Web of Science, BIOSIS Previews, Clarivate Analytics, etc. See https:// horizonepublishing.com/journals/index.php/ PST/indexing_abstracting

Copyright: ( $)$ The Author(s). This is an openaccess article distributed under the terms of the Creative Commons Attribution License, which permits unrestricted use, distribution and reproduction in any medium, provided the original author and source are credited (https://creativecommons.org/licenses/ by/4.0/)

\section{CITE THIS ARTICLE}

Hoque T S, Abedin M A, Kibria M G, Jahan I, Hossain M A. Application of moringa leaf extract improves growth and yield of Tomato (Solanum lycopersicum) and Indian Spinach (Basella alba). Plant Science Today. 2022;9 (1):137-143. https://doi.org/10.14719/ pst.1353

\begin{abstract}
Moringa (Moringa oleifera L.) leaf extract is a natural plant growth stimulant that is well-known for its ability to improve plant growth and development. A field study was conducted to evaluate the influence of MLE (Moringa Leaf Extract) on the growth, yield and nutritional improvement in two vegetable crops [Tomato (Solanum lycopersicum) and Indian Spinach (Basella alba)]. The extract was applied at two weeks interval with different frequencies. The crops were fertilized with chemical fertilizers and MLE application was done as per treatment @ $25 \mathrm{ml} /$ plant. For each of the crops, this biostimulant had a significant boosting effect on growth, yield and nutrient uptake whereas the maximum frequency in the application i.e. $\mathrm{T}_{4}$ (foliar application of MLE at 2 weeks after transplanting and application at every 2 weeks thereafter) showed the highest influence. Indian Spinach responded proportionally more to foliar-applied MLE in terms of plant growth and nutrient uptake compared to tomato. The effect of MLE on the yield parameters was more pronounced in tomato that showed a 25\% (averaged across all the growth parameters) increase over control, but Indian Spinach showed $\sim 20 \%$ increase in yield parameters compared to control. Therefore, applying MLE to the foliage may assist in increasing the yield by improving plant growth across the different vegetable species (e.g., Tomato and Indian Spinach).
\end{abstract}

\section{Keywords \\ bio-stimulant, MLE, nutrient uptake, growth and yield}

\section{Introduction}

Modern agricultural production aims to provide sustainable management practices that are eco-friendly and low cost. In recent years, the natural plant growth enhancer is the main focus of study for many researchers around the globe (1). Moringa (Moringa oleifera L.) leaves are used as green manure and as a potential natural growth stimulant (2). The extract prepared from fresh moringa leaves is a unique source of vitamins, hormones, antioxidants, osmoprotectants, carotenoids, polyphenols, phenolic acids, flavonoids, alkaloids, glucosinolates, isothiocyanates, tannins, saponins and secondary metabolites (3-5). The presence of a significant quantity of phytohormones such as cytokinin, gibberellin, indole-3-acetic acid, zeatin, mineral nutrient elements, vitamins such as ascorbic acid, carotenoid, antioxidants such as flavonoid and phytochemicals like phenolics, glucosin- 
olates and isothiocyanates, osmoprotectants in MLE has made it an effective plant bio-stimulant $(4,5)$. When MLE is exogenously applied to plants, it has the potential to act as a growth promoter to increase the production of many vegetable and field crops (6). The foliar use of MLE can contribute to improve physiological and biochemical attributes of plants such as photosynthetic and enzymatic activities, which appropriate the efficiency of utilizing nutrients leading to enhanced plant growth and productivity. Many recent research findings have suggested the use of MLE as a biostimulant to accelerate vegetative and reproductive growth, antioxidant defense and yield under normal and stressed conditions (7-9).

Bangladesh is an agrarian country where agriculture is the mainstay of the country's economy contributing largely to the Gross Domestic Product (GDP) and serving as the greatest employment sector for its people (10). Vegetables are considered as an important source of vitamins and minerals $(11,12)$. Thus, a balanced intake of cereals and vegetables is extremely important for the daily dietary requirement of the increasing population. Vegetable production in Bangladesh is currently inadequate to fulfill the nutritional demand of the people due to the limited production system. Bangladesh is facing a great challenge in agricultural food production for its ever-rising population with the shrinkage of agricultural lands (10). Our land quality is deteriorating day by day due to degradation of soil fertility, nutrient mining, depletion of organic matter, soil and water pollution, soil salinity, acidity and long-term water logging problems. Traditional agricultural practices often threaten soil and human health, degrade agricultural environment, and destroy agricultural biodiversity. For the improvement of soil health and crop productivity, this is essential to develop an eco-friendly sustainable approach for increasing agricultural productivity in the context of Bangladesh.

The modern agricultural system should give attention to conserve agricultural biodiversity and should adopt sustainable techniques. Application MLE to the foliage as a bio-stimulant is an established readily available sustainable approach for increasing yields of crops with minimum input cost (13). Furthermore, moringa leaves can be used in feed production, medicinal purposes, seed multiplication and eco-friendly pesticides for its high nutritional value (14-17). The beneficial effects of moringa leaves should be incorporated into the modern farming practices for sustainable plant growth and priority should be given to research related to moringa to highlight its roles in agriculture for the welfare of the smallholder farmers. Still now, there are a few reports that illustrate the effects of MLE on field and vegetable crops at a time. The performance of MLE in different crops should be judged to find out its suitability in a large-scale application. Therefore, the experiment was conducted to assess the effectiveness of the foliar application of MLE to enhance plant growth, yield and nutrient uptake of tomato and Indian Spinach for developing a sustainable agricultural production system.

\section{Materials and Methods}

\section{Experimental location and soil condition}

The research work was conducted during the Rabi season at the field of the Department of Soil Science, Bangladesh Agricultural University $\left(24^{\circ} 75^{\prime} \mathrm{N}, 90^{\circ} 50^{\prime} \mathrm{E}\right)$. The welldrained medium high land (18 $\mathrm{m}$ above sea level) falls within the Sonatala series with non-calcareous floodplain soil (AEZ 9: Old Brahmaputra Floodplain). The physicochemical properties of the selected soil samples have been presented in Table 1.

\begin{tabular}{lc} 
Table 1. Soil characteristics before starting the experiments & \\
\hline Properties & Values \\
\hline Soil pH $\mathrm{p}_{0.01} \mathrm{~m} \mathrm{CaCl}$ & 6.58 \\
Organic matter content wet oxidation $(\%)$ & 1.25 \\
Total N (\%) & 0.162 \\
Available P (ppm) & 10.83 \\
Exchangeable K (meq/100 g soil) & 0.067 \\
Available S (ppm) & 9.88 \\
Soil texture & Silt loam
\end{tabular}

\section{Plant materials, experimental design and approach}

In this study, Tomato (Solanum lycopersicum cv. Roma VF) and Indian Spinach (Basella alba cv. Red Malabar) were used as test crops. Twenty five days-old seedlings were transplanted in the experimental plots maintaining line to line distance $60 \mathrm{~cm}$ and plant to plant distance $50 \mathrm{~cm}$. Both of the crops were grown in the experimental plots with the same treatments and the treatments were replicated three times in a randomized complete block design (RCBD). The four treatments [ $T_{1}$ (control: 0 foliar MLE); $T_{2}$ (foliar application of MLE at 2 weeks after seedling transplanting); $\mathrm{T}_{3}$ (application of MLE to the foliage at 2 and 4 weeks after seedling transplanting) and $\mathrm{T}_{4}$ (applying foliar MLE at 2 weeks after seedling transplanting and continued to apply at every 2 weeks thereafter)] were used for each of the test crops. The total number of plots $\left(2.5 \times 2 \mathrm{~m}^{2}\right)$ was 12 for each crop ( 4 treatments $\times 3$ replications), thus 24 plots (separated by $0.5 \mathrm{~m}$ spacing) were used for growing two vegetable crops. Each plot was amended with the recommended dose of chemical fertilizers (18) to supply nutrients to soil during land preparation. The recommended doses of phosphorus $(P)$, potassium $(K)$, sulphur $(S)$, zinc $(\mathrm{Zn})$ and boron (B) were 45, 40, 14, 1.5 and $1 \mathrm{~kg} / \mathrm{ha}$, respectively for tomato but 20, 22, 5, 1.5 and $1 \mathrm{~kg} / \mathrm{ha}$, respectively for Indian Spinach. Urea was applied in three equal splits to supply nitrogen (N) at 120 and $105 \mathrm{~kg} /$ ha for tomato and Indian Spinach, respectively. The first split was applied with the basal dose whereas the $2^{\text {nd }}$ and $3^{\text {rd }}$ splits of urea were applied at 30 and 45 days after transplanting. Various intercultural operations such as weeding, fencing, gap filling and pesticide application were performed as and when required.

\section{Collection, preparation and foliar application of MLE}

Fresh and young moringa leaves (30-40 days old) were collected from mature plants. Approximately, $10 \mathrm{~g}$ leaves 
were washed properly and transferred into a mortar with a little amount of distilled water ( $1 \mathrm{ml} / 10 \mathrm{~g}$ moringa leaves) to grind using pestle. The leaf extract was collected by pressing with hand and filtered through a Whatman filter paper (No 2). The collected extract was mixed with distilled water (extract: water $=1: 0.32)(\mathrm{v} / \mathrm{v})$ and kept in a plastic bottle for applying to the foliage (8). The prepared leaf extract was used for foliar application to plants and the unused MLE was stored at $0{ }^{\circ} \mathrm{C}$ temperature in a refrigerator for further use. The MLE was applied to the foliage (at 25 $\mathrm{ml} /$ plant) for each crop as per treatment using a hand sprayer (during late afternoon) until the plants were completely wet. For control plots, each plant was amended with $25 \mathrm{ml}$ of distilled water (without MLE). Each plot was watered and monitored daily to avoid drought and waterlogging stress. Each crop was harvested at its maturity followed by recording different growth and yield parameters.

\section{Nutrient analysis of plants}

The fruits and leaves of tomato and the leaves and stems of Indian Spinach were considered for chemical analysis. The samples were dried at $65^{\circ} \mathrm{C}$ for $48 \mathrm{hrs}$ in an oven, weighed and ground for preparing a homogenous mixture (by passing through a 20-mesh sieve). The prepared samples were analyzed for N, P, K and S concentration following standard methods to calculate the total nutrient uptake by plants $(19,20)$.

\section{Statistical analysis}

The data were subjected to one-way analysis of variance (ANOVA) for each crop followed by Duncan's Multiple Range Test (DMRT) to identify significant (5\% level of probability) differences among the treatments using the MSTATCcomputer package program $(21,22)$.

\section{Results}

\section{Effect of MLE on Tomato}

Application of MLE to the foliage exhibited a significant increase in plant growth parameters of tomato compared to control plants irrespective of the number of applications, except for number of branches per plant and root dry weight (Table 2). The highest values of the growth parameters such as plant height $(114.3 \mathrm{~cm})$, number of branches plant $^{-1}$ (10.3), number of leaves plant ${ }^{-1}$ (46.7), shoot dry weight $(18.2 \mathrm{~g})$, root dry weight $(21 \mathrm{~g})$ and rooting depth $(35.7 \mathrm{~cm})$ were found in MLE treated plants at 2 weeks and after every two weeks thereafter compared to the other treatments. Applying MLE at every 2 weeks' interval significantly increased plant growth by at least $~ 15 \%$ compared to the plants treated with no foliar MLE (Fig. 1). All the yield parameters also exhibited a significant increase in response to foliar application of MLE, except largest fruit length (Table 3). Similar to the growth parameters, the maximum values of yield components viz. number of flowers plant ${ }^{-1}$ (57.7), number of fruits plant ${ }^{-1}(50.8)$, largest fruit weight $(62.7 \mathrm{~g})$, largest fruit length $(5.9 \mathrm{~cm})$ and fruit yield $\left(39 \mathrm{t} \mathrm{ha}^{-1}\right)$ were observed in the plants treated with MLE at every 2 weeks' interval. Applying MLE to the foliage at 2 weeks and after every two weeks thereafter significantly increased the yield parameters of tomato by at least $\sim 19 \%$ compared to control (Fig. 2).

Spraying of MLE caused a significant increase in nutrient uptake by plants compared to control irrespective of the number of applications, except $S$ uptake in tomato fruits (Table 4). The highest nutrient uptakes by fruit (546.3 $\mathrm{kg} \mathrm{N} \mathrm{ha}^{-1}, 13.9 \mathrm{~kg} \mathrm{P} \mathrm{ha}^{-1}, 149.3 \mathrm{~kg} \mathrm{~K} \mathrm{ha}^{-1}$ and $6.8 \mathrm{~kg} \mathrm{~S} \mathrm{ha}^{-1}$ ) and by leaf $\left(700.1 \mathrm{~kg} \mathrm{~N} \mathrm{ha}^{-1}, 119 \mathrm{~kg} \mathrm{P} \mathrm{ha}^{-1}, 161.1 \mathrm{~kg} \mathrm{~K} \mathrm{ha}^{-1}\right.$ and $28.1 \mathrm{~kg} \mathrm{~S} \mathrm{ha}^{-1}$ ) were observed by foliar application of MLE at every 2 weeks' interval. Among the macronutrients, $\mathrm{N}$ and $\mathrm{P}$ uptake were increased by $\sim 45 \%$ (averages across leaf and fruit) and $\mathrm{K}$ and $\mathrm{S}$ uptake were increased by at least $~ 37 \%$ in MLE treated plants at 2 weeks and after every two weeks thereafter compared to the plants treated with no foliar MLE (Fig. 3).

\section{Effect of MLE on Indian Spinach}

Foliar use of MLE showed a significant positive effect on the growth parameters of Indian Spinach irrespective of the number of applications compared to when no MLE was ap-

Table 2. Effect of foliar application of MLE on growth parameters of Tomato and Indian Spinach

\begin{tabular}{|c|c|c|c|c|c|c|}
\hline \multicolumn{7}{|c|}{ Tomato } \\
\hline Treatments & $\begin{array}{l}\text { Plant height } \\
\text { (cm) }\end{array}$ & $\begin{array}{l}\text { Number of branches } \\
\text { plant }^{-1}\end{array}$ & $\begin{array}{c}\text { Number of leaves } \\
\text { plant }^{-1}\end{array}$ & $\begin{array}{c}\text { Shoot dry weight } \\
\left.\text { (g plant }^{-1}\right)\end{array}$ & $\begin{array}{c}\text { Root dry weight } \\
\left.\text { (g plant }^{-1}\right)\end{array}$ & $\begin{array}{l}\text { Rooting depth } \\
(\mathrm{cm})\end{array}$ \\
\hline $\mathrm{T}_{1}$ & $99.8 \mathrm{C}$ & 8.1 & $37.3 c$ & $14.8 \mathrm{~b}$ & 17.4 & $30.7 \mathrm{c}$ \\
\hline $\mathrm{T}_{2}$ & $107.3 b$ & 8.8 & $40.7 b c$ & $15.7 \mathrm{~b}$ & 19.2 & 31.6 bc \\
\hline $\mathrm{T}_{3}$ & $110.8 \mathrm{ab}$ & 9.5 & $43 a b$ & $17.1 \mathrm{~b}$ & 19.9 & $33.7 \mathrm{ab}$ \\
\hline $\mathrm{T}_{4}$ & $114.3 \mathrm{a}$ & 10.3 & $46.7 \mathrm{a}$ & $18.2 \mathrm{a}$ & 21 & $35.7 \mathrm{a}$ \\
\hline SE $( \pm)$ & 1.1 & $1.3(\mathrm{~ns})$ & 1.2 & 1.2 & 1.1 (ns) & 0.8 \\
\hline \multicolumn{7}{|c|}{ Indian Spinach } \\
\hline Treatments & $\begin{array}{l}\text { Plant height } \\
(\mathbf{c m})\end{array}$ & $\begin{array}{l}\text { Number of branches } \\
\text { plant }^{-1}\end{array}$ & $\begin{array}{l}\text { Number of leaves } \\
\text { plant }^{-1}\end{array}$ & $\begin{array}{l}\text { Leaf } \\
\text { length } \\
\text { (cm) }\end{array}$ & $\begin{array}{c}\text { Stem } \\
\text { length } \\
(\mathrm{cm})\end{array}$ & $\begin{array}{l}\text { Rooting depth } \\
(\mathrm{cm})\end{array}$ \\
\hline $\mathrm{T}_{1}$ & $53.7 \mathrm{~d}$ & 4.3 & $39.3 b$ & $12.3 \mathrm{~b}$ & $28.3 \mathrm{~b}$ & $25.3 b$ \\
\hline $\mathrm{T}_{2}$ & $58.3 \mathrm{c}$ & 4.7 & $42.3 \mathrm{ab}$ & $13.4 \mathrm{ab}$ & $30.3 a b$ & $28 a b$ \\
\hline $\mathrm{T}_{4}$ & $71 \mathrm{a}$ & 5.5 & $49.3 \mathrm{a}$ & $17 \mathrm{a}$ & $38 \mathrm{a}$ & $33.3 \mathrm{a}$ \\
\hline SE $( \pm)$ & 1.1 & 0.6 (ns) & 2.1 & 1.3 & 1.6 & 2.1 \\
\hline
\end{tabular}

Figures in a column having common letter(s) or without letters do not differ significantly at $5 \%$ level of significance according to DMRT. Values are means \pm SE of three replicates. $n s=$ Not significant; $\mathrm{SE}=$ Standard error of means; $\mathrm{T}_{1}=$ Control; $\mathrm{T}_{2}=\mathrm{MLE}$ applied at 2 weeks after transplanting; $\mathrm{T}_{3}=\mathrm{MLE}$ applied at 2 weeks and 4 weeks after transplanting; $T_{4}=$ MLE applied at 2 weeks after transplanting and after every two weeks thereafter 

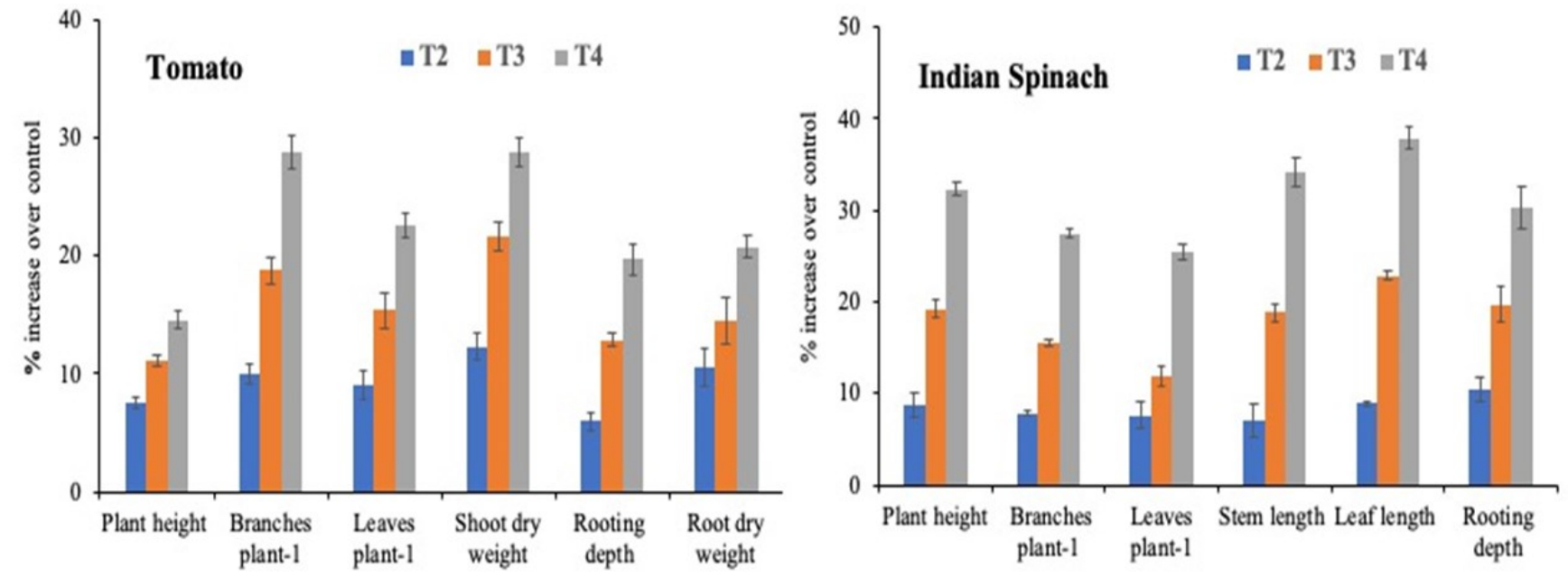

Fig. 1. Percentage increase in growth parameters of Tomato and Indian Spinach over control as affected by the application of MLE. The effect of foliar application of MLE was significant at $P \leq 0.05$. Values are means $\pm S E$ of three replicates. $T_{2}=M L E$ applied at 2 weeks after transplanting; $T_{3}=M L E$ applied at 2 weeks and 4 weeks after transplanting; $T_{4}=$ MLE applied at 2 weeks after transplanting and after every two weeks thereafter

Table 3. Effect of foliar application of MLE on yield parameters of Tomato and Indian Spinach

Indian spinach

\begin{tabular}{|c|c|c|c|c|c|c|c|c|c|}
\hline Treatments & $\begin{array}{l}\text { Number of } \\
\text { flowers }^{\text {plant }}{ }^{-1}\end{array}$ & $\begin{array}{c}\text { Number of } \\
\text { fruits } \\
\text { plant }^{-1}\end{array}$ & $\begin{array}{l}\text { Largest } \\
\text { fruit } \\
\text { weight } \\
\text { (g) }\end{array}$ & $\begin{array}{l}\text { Largest } \\
\text { fruit } \\
\text { length } \\
\text { (cm) }\end{array}$ & $\begin{array}{c}\text { Fruit } \\
\text { yield } \\
\left(\mathrm{t} \mathrm{ha}^{-1}\right)\end{array}$ & 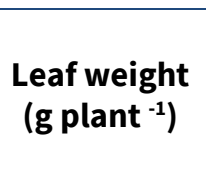 & $\begin{array}{c}\text { Leaf } \\
\text { yield } \\
\left(t \text { ha }^{-1}\right)\end{array}$ & $\begin{array}{l}\text { Stem weight } \\
\left.\text { (g plant }^{-1}\right)\end{array}$ & $\begin{array}{c}\text { Stem } \\
\text { yield } \\
\left(\mathrm{t} \mathrm{ha}^{-1}\right)\end{array}$ \\
\hline $\mathrm{T}_{1}$ & $46.3 c$ & $39.3 c$ & $53.9 \mathrm{c}$ & 4.9 & $33.3 \mathrm{~b}$ & $128.7 \mathrm{c}$ & $6.4 c$ & $171 \mathrm{c}$ & $8.8 \mathrm{~b}$ \\
\hline $\mathrm{T}_{2}$ & $52 \mathrm{~b}$ & $46 \mathrm{~b}$ & $56.9 b$ & 5.2 & $34.6 \mathrm{~b}$ & $136.7 \mathrm{bc}$ & $6.8 \mathrm{~b}$ & $185.3 \mathrm{~b}$ & $8.9 \mathrm{~b}$ \\
\hline $\mathrm{T}_{3}$ & $54.7 \mathrm{ab}$ & $48 \mathrm{ab}$ & $60.9 a$ & 5.8 & $36.4 \mathrm{ab}$ & $147 \mathrm{ab}$ & $7.3 a b$ & $198.3 \mathrm{a}$ & $9.9 a b$ \\
\hline $\mathrm{T}_{4}$ & 57.7 a & $50.8 \mathrm{a}$ & $62.7 \mathrm{a}$ & 5.9 & $39 a$ & $154.7 \mathrm{a}$ & $7.7 \mathrm{a}$ & $209.2 \mathrm{a}$ & $10.4 \mathrm{a}$ \\
\hline $\mathrm{SE}( \pm)$ & 1.1 & 0.8 & 0.9 & $0.7(\mathrm{~ns})$ & 1.3 & 3.6 & 0.7 & 3.3 & 1.5 \\
\hline
\end{tabular}

Figures in a column having common letter(s) or without letters do not differ significantly at $5 \%$ level of significance according to DMRT. Values are means \pm SE of three replicates. $\mathrm{ns}=$ Not significant; $\mathrm{SE}=$ Standard error of means; $\mathrm{T}_{1}=$ Control; $\mathrm{T}_{2}=\mathrm{MLE}$ applied at 2 weeks after transplanting; $\mathrm{T}_{3}=\mathrm{MLE}$ applied at 2 weeks and 4 weeks after transplanting; $T_{4}=$ MLE applied at 2 weeks after transplanting and after every two weeks thereafter
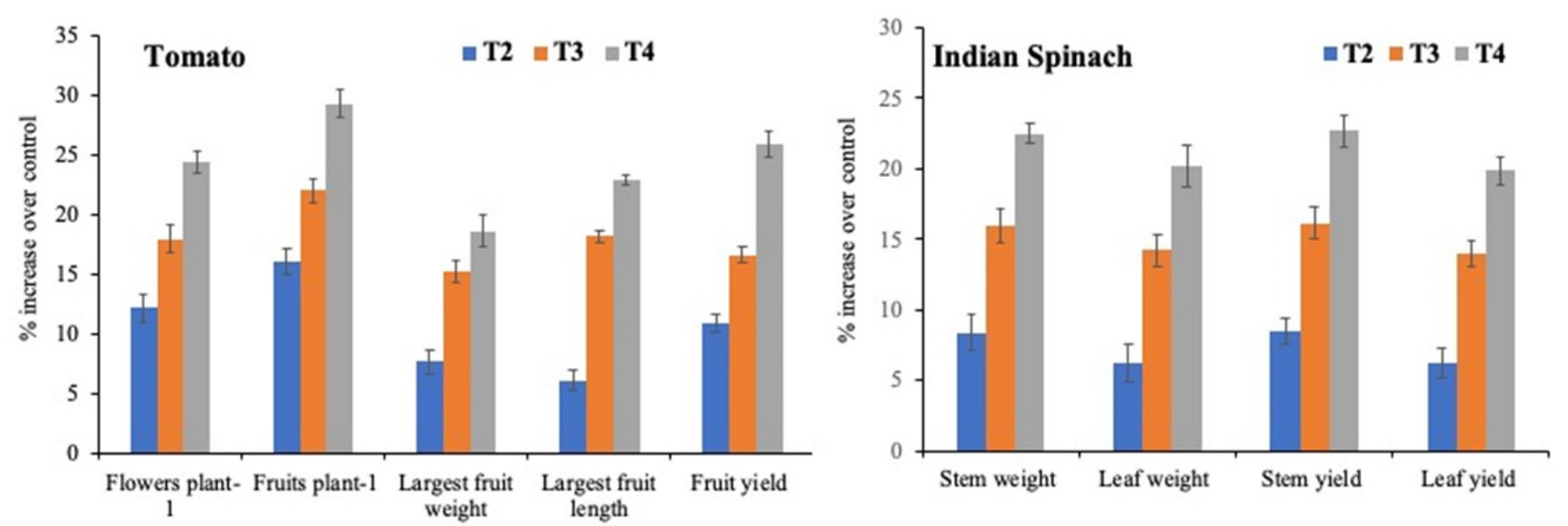

Fig. 2. Percentage increase in yield parameters and yield of Tomato and Indian Spinach over control as affected by the application of MLE. The effect of foliar application of MLE was significant at $\mathrm{P} \leq 0.05$. Values are means $\pm \mathrm{SE}$ of three replicates. $\mathrm{T}_{2}=\mathrm{MLE}$ applied at 2 weeks after transplanting; $\mathrm{T}_{3}=\mathrm{MLE}$ applied at 2 weeks and 4 weeks after transplanting; $\mathrm{T}_{4}=\mathrm{MLE}$ applied at 2 weeks after transplanting and after every two weeks thereafter

plied (control), except for number of branches per plant However, the percent increase over control was significant(Table 2). The maximum plant height $(71 \mathrm{~cm})$, number of ly higher when MLE was applied twice $\left(T_{3}\right)$. Repetitive applibranches plant ${ }^{-1}$ (5.5), number of leaves plant ${ }^{-1}$ (49.3), leaf cation of MLE to foliage $\left(\mathrm{T}_{4}\right)$ showed $\sim 30 \%$ increase in plant length $(17 \mathrm{~cm})$, stem length $(38 \mathrm{~cm})$ and rooting depth $(33.3$ height, stem length, leaf length and rooting depth and $\mathrm{cm}$ ) were noted in treatment $\mathrm{T}_{4}$ that received MLE at $2 \sim 25 \%$ increase in number of leaves and branches per plant weeks and after every two weeks thereafter. Application of compared to control (Fig. 1). The yield parameters and yield MLE at 2 weeks after transplanting $\left(\mathrm{T}_{2}\right)$ increased (7-10.5\%) of Indian Spinach were also significantly influenced by MLE all the growth parameters compared to control (Fig. 1). application as shown in Table 3 and the highest leaf weight 
Table 4. Effect of foliar application of MLE on nutrient uptake by Tomato and Indian Spinach

\begin{tabular}{|c|c|c|c|c|c|c|c|c|}
\hline \multicolumn{9}{|c|}{ Tomato } \\
\hline \multirow{2}{*}{ Treatments } & \multicolumn{2}{|c|}{ N (kg/ha) } & \multicolumn{2}{|c|}{$P(\mathrm{~kg} / \mathrm{ha})$} & \multicolumn{2}{|c|}{ K (kg/ha) } & \multicolumn{2}{|c|}{$\mathrm{S}$ (kg/ha) } \\
\hline & Fruit & Leaf & Fruit & Leaf & Fruit & Leaf & Fruit & Leaf \\
\hline $\mathrm{T}_{1}$ & $396.2 \mathrm{~d}$ & $468.1 \mathrm{~d}$ & $9.37 c$ & $81.1 \mathrm{~d}$ & $111.5 \mathrm{~d}$ & $111.1 \mathrm{~d}$ & 4.7 & $18.7 \mathrm{~b}$ \\
\hline $\mathrm{T}_{2}$ & $446.3 c$ & $515.5 \mathrm{c}$ & $11.4 \mathrm{~b}$ & $95.2 \mathrm{c}$ & $128.0 \mathrm{c}$ & $130.2 \mathrm{c}$ & 5.5 & $22.3 \mathrm{ab}$ \\
\hline $\mathrm{T}_{3}$ & $476.8 \mathrm{~b}$ & $620.4 b$ & $13.0 \mathrm{a}$ & $106.8 \mathrm{~b}$ & $138.3 b$ & $150.8 \mathrm{~b}$ & 6.0 & $25.2 \mathrm{ab}$ \\
\hline $\mathrm{T}_{4}$ & $546.3 \mathrm{a}$ & $700.1 \mathrm{a}$ & $13.9 \mathrm{a}$ & $119.0 \mathrm{a}$ & $149.3 \mathrm{a}$ & $161.1 \mathrm{a}$ & 6.8 & $28.1 \mathrm{a}$ \\
\hline $\mathrm{SE}( \pm)$ & 1.19 & 3.64 & 0.41 & 1.48 & 1.88 & 0.68 & 0.94 (ns) & 2.07 \\
\hline \multicolumn{9}{|c|}{ Indian Spinach } \\
\hline \multirow{2}{*}{ Treatments } & \multicolumn{2}{|c|}{$N(k g / h a)$} & \multicolumn{2}{|c|}{$P(k g / h a)$} & \multicolumn{2}{|c|}{ K (kg/ha) } & \multicolumn{2}{|c|}{ S (kg/ha) } \\
\hline & Stem & Leaf & Stem & Leaf & Stem & Leaf & Stem & Leaf \\
\hline $\mathrm{T}_{1}$ & $216.2 d$ & $174.2 \mathrm{c}$ & $20.2 b$ & $24.9 \mathrm{~b}$ & $52.1 \mathrm{c}$ & $85.8 b$ & 15.4 & 14.3 \\
\hline $\mathrm{T}_{2}$ & $246.9 \mathrm{c}$ & $191.6 \mathrm{~b}$ & $24.6 \mathrm{ab}$ & 29.2 b & 60.2 bc & $100.4 b$ & 18.1 & 16.6 \\
\hline $\mathrm{T}_{3}$ & $291 b$ & $240.1 \mathrm{a}$ & $26.4 \mathrm{ab}$ & $34.1 \mathrm{a}$ & $66.2 b$ & $117.5 \mathrm{a}$ & 20.2 & 18.0 \\
\hline $\mathrm{T}_{4}$ & $324.4 \mathrm{a}$ & $267.2 \mathrm{a}$ & $30.0 \mathrm{a}$ & $37.4 \mathrm{a}$ & $77.9 \mathrm{a}$ & $131.2 \mathrm{a}$ & 22.4 & 20.3 \\
\hline SE $( \pm)$ & 2.9 & 6.3 & 2.2 & 1.4 & 2.4 & 4.3 & 3.9 (ns) & 2.6 (ns) \\
\hline
\end{tabular}

Figures in a column having common letter(s) or without letters do not differ significantly at $5 \%$ level of significance according to DMRT. Values are means \pm SE of three replicates. $\mathrm{ns}=$ Non significant; $\mathrm{SE}=$ Standard error of means; $\mathrm{T}_{1}=$ Control; $\mathrm{T}_{2}=\mathrm{MLE}$ applied at 2 weeks after transplanting; $\mathrm{T}_{3}=\mathrm{MLE}$ applied at 2 weeks and 4 weeks after transplanting and $\mathrm{T}_{4}=\mathrm{MLE}$ applied at 2 weeks after transplanting and after every two weeks thereafter.
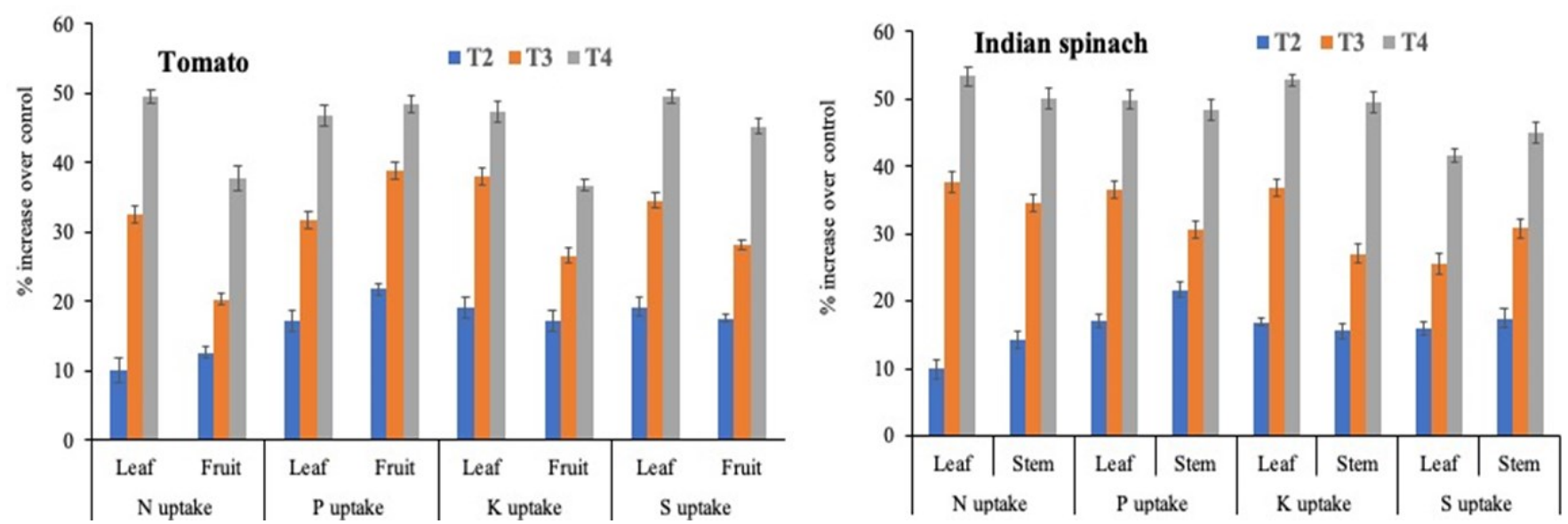

Fig. 3. Percentage increase in N, P, K and S uptake in Tomato and Indian Spinach over control as affected by the application of MLE. The effect of foliar application of MLE was significant at $P \leq 0.05$. Values are means \pm SE of three replicates. $T_{2}=M L E$ applied at 2 weeks after transplanting; $T_{3}=M L E$ applied at 2 weeks and 4 weeks after transplanting; $T_{4}=$ MLE applied at 2 weeks after transplanting and after every two weeks thereafter

(154.7 g plant $^{-1}$ ), leaf yield (7.7 $\left.\mathrm{t} \mathrm{ha}^{-1}\right)$, stem weight (209.2 $\mathrm{g} \mathrm{kg} \mathrm{P} \mathrm{ha}^{-1}, 131.2 \mathrm{~kg} \mathrm{~K} \mathrm{ha}^{-1}$ and $20.3 \mathrm{~kg} \mathrm{~S}^{-1}$ ) compared to no plant $^{-1}$ ) and stem yield (10.4 $\mathrm{t} \mathrm{ha}^{-1}$ ) were recorded with max- foliar MLE (Table 4). The uptakes of $\mathrm{N}$ and $\mathrm{K}$ were increased imum MLE application $\left(\mathrm{T}_{4}\right)$. The leaf yield as well as stem by $\sim 50 \%$, whereas $\mathrm{P}$ and $\mathrm{S}$ uptakes were improved by at yield also exhibited the highest percent increase (20\%) over least $42 \%$ when MLE was applied at 2 weeks' interval ( $\left.T_{4}\right)$ control when MLE was applied to the foliage at 2 weeks and over control (Fig. 3). .

after every two weeks thereafter (Fig. 2).

Uptakes of nutrients viz. N, P, K and S by Indian Spinach were significantly increased by foliar application of MLE compared to control ( 0 foliar MLE), except for S uptake by plant (Table 4). Applying MLE to the foliage at 2 weeks and after every two weeks thereafter $\left(\mathrm{T}_{4}\right)$ exhibited the highest nutrient uptakes by stem (324.4 kg N ha-1, $30 \mathrm{~kg} \mathrm{P} \mathrm{ha}^{-1}, 77.9$ $\mathrm{kg} \mathrm{K} \mathrm{ha}^{-1}$ and $\left.22.4 \mathrm{~kg} \mathrm{~S} \mathrm{ha}^{-1}\right)$ and by leaf (267.2 $\mathrm{kg} \mathrm{N} \mathrm{ha}^{-1}, 37.4$

\section{Discussion}

Plant growth and yield were likely to increase by applying MLE to the foliage. In this study, foliar application of MLE contributed to increase the growth and yield of tomato and Indian Spinach compared to when no MLE was applied to the foliage (Table 2 and 3; Fig. 1 and 2). The observed in- 
crease in plant growth in response to foliar MLE application is consistent with those reported from other and/or similar crop species $(5,6)$. The enhanced plant growth following MLE application has also been reported in previous studies mentioning that MLE acts as a biostimulator for enhancing the mineral nutrient use efficiency and promotes plant growth $(2,25)$. This might have occurred due to having a cytokinin hormone (zeatin) in the extract, which acts as a stimulator for plant growth and productivity (23-25). It has been argued that an external supply of MLE to the foliage increases plant growth, which contributes to the increased yield of different plants $(1,24)$. These findings suggest that foliar application of MLE enhances crop yield by increasing growth parameters. Our results suggest that providing an external supply of MLE to the foliage could be one of the best possible ways for enhancing vegetable crop production. It has already been reported that applying MLE to the foliage significantly increased the growth and yield of different vegetables and legume crops compared to control $(1,26,27)$.

Given the positive response, it is essential to find the time and frequency of MLE applications to the foliage to get maximum return in terms of growth and yield. Results from the present study demonstrated that application of MLE at every 2 weeks' interval increased plant growth (Table 2) and yield (Table 3 ) of all the plant species. In contrast, foliar application of MLE at 2 weeks $\left(T_{2}\right)$ and twice application at 2 and 4 weeks $\left(T_{3}\right)$ didn't increase plant growth and yield to the same extent as applying MLE at every 2 weeks' interval. However, detailed characterization of the optimum rate of MLE application to the foliage to get maximum economic return deserves further investigation. Applying MLE to the foliage at every 2 weeks' interval enhanced plant growth by $\sim 25 \%$ (averaged across all the plant growth parameters), which is critical for increasing crop yield. The increase in plant growth following foliar MLE application varied among the crop species. For example, the positive effect of MLE on plant growth was more pronounced in Indian Spinach compared to tomato (Table 2; Fig. 1). A possible explanation of the more pronounced effect on leafy vegetables could be due to the contribution in producing the greatest number of leaves, thus it leads to increased yield of Indian Spinach. Although the response to foliar-applied MLE was proportionately more in Indian Spinach, tomato also exhibited a significant increase in plant yield contributing parameters compared to Indian Spinach.

In the present study, the external supply of MLE to the foliage significantly increased nutrient uptake by all the plants compared to no MLE application to the foliage (Table 4; Fig. 3). It can be explained from previous research findings, those suggested that MLE is one of the best sources for supplying nutrient elements for stimulating plant growth and productivity $(29,30)$. It has already been reported that application of MLE to the foliage contributed to enhance the nutrient uptake of a number of plant species $(1,2,23,28)$. The increased nutrient uptake in response to foliar-applied moringa leaf extract has also been reported in some metatherian plant species (31), cabbage (1), and pea (28). Thus, MLE acts as a bio-stimulator for increasing nutrient uptake, which leads to improved plant growth and productivity (1). Therefore, we suggest applying MLE to the foliage to increase the uptake of essential elements and increase the nutritional value of plant products.

\section{Conclusion}

We conclude that applying MLE to the foliage (at $25 \mathrm{ml} /$ plant) facilitated the growth and yield of both Tomato and Indian Spinach. The effect of MLE was more pronounced in Indian Spinach in terms of growth parameters compared to tomato. Moreover, the application of MLE enhanced the nutrient uptake by plants, which finally contribute to increase the yield components. As foliar application of MLE improved the performance of tomato and Indian Spinach simultaneously, farmers and agronomists could apply MLE to the foliage to improve plant growth and yield for a sustainable agricultural production system. Determining the potential of MLE as a biostimulant for vegetable production is critical to improve their nutritional quality. The correct amount and proper time for MLE application is crucial to get the maximum benefits from its application to crops. In this research, we highlighted the possible rate and frequencies of MLE application on tomato and Indian Spinach which will help maintain balanced use of MLE as a foliar spray to enhance production and quality of these two vegetable crops. This study showed the nutritional improvement in different plant organs due to MLE application in these vegetables which was not previously reported. Further research should focus on assessing the effectiveness of foliar-applied MLE for mitigation of different abiotic stress on plants, such as drought, salinity, acidity etc.

\section{Acknowledgements}

This study was funded by the Ministry of Science and Technology, Government of the People's Republic of Bangladesh.

\section{Authors contributions}

Conceptualization: TSH and MAA; Methodology and Supervision: TSH and MAA; Investigation: TSH, MAA and IJ; Data analysis: IJ and MGK; Writing-original draft preparation: TSH, MGK and IJ; Writing-review and editing: MAH.

\section{Compliance with ethical standards}

Conflict of interest: The authors do not have any conflict of interests to declare.

Ethical issues: None.

\section{References}

Hoque TS, Rana MS, Jahan SA, Jahan I, Abedin MA. Moringa leaf extract as a bio-stimulant on growth, yield and nutritional improvement in cabbage. Asian J Med and Biol Res. 2020;6:196-203. 
https://doi.org/ 10.3329/ajmbr.v6i2.48050

2. Fuglie LJ. The Miracle Tree: Moringa oleifera: Natural nutrition for 17 the Tropics. The Multiple Attributes of Moringa. Int. J. Adv. Res. Ideas Innov. Tehnol. 2000;3:172.

3. Gopalakrishnan L, Doriya K, Kumar DS. Moringa oleifera: A review on nutritive importance and its medicinal application. Food Sci Hum Wellness. 2016;5(2):49-56. https://doi.org/10.1016/ j.fshw.2016.04.001

4. Rady MM, Mohamed GF. Modulation of salt stress effects on the growth, physiochemical attributes and yields of Phaseolus vulgaris L. plants by the combined application of salicylic acid and Moringa oleifera leaf extract. Sci Hortic. 2015;193:105-13. https:// doi.org/10.1016/J.SCIENTA.2015.07.003

5. Leone A, Spada A, Battezzati A, Schiraldi A, Aristil J, Bertoli S. Cultivation, genetic, ethnopharmacology, phytochemistry and pharmacology of Moringa oleifera leaves: An overview. Int J Mol Sci. 2015;16:12791-835. https://doi.org/10.3390/ijms160612791.

6. Ozobia AP. Comparative assessment of effect of moringa extracts, NPK fertilizer and poultry manure on soil properties and growth performance of Solanum melongina in Abuja, North Central Region of Nigeria. J Agric Crop Res. 2014;2:88-93.

7. Aluko M, Ayodele OJ, Gbadeola AS, Oni IH. Comparative effects of varying rates of moringa leaf, poultry manure and NPK fertilizer on the growth, yield and quality of okra (Abelmoschus esculentus L. Moench). Int J Environ Agric Biotechnol. 2017;2:2901-2907. https://doi.org/10.22161/ijeab/2.6.17

8. Hala H, El-Noor A, Ewais NA. Effect of Moringa oleifera leaf extract (MLE) on pepper seed germination, seedlings improvement, growth, fruit yield and its quality. Middle East J Agric Res. 2017;6:448-63.

9. Prabhu MA, Kumar AR, Rajamani K. Influence of different organic substances on growth and herb yield of sacred basil (Ocimum sanctum L.). Indian J Agric Res. 2010;44:48-52.

10. Bangladesh Bureau of Statistics (BBS), Statistics and Informatics Division, Ministry of Planning, Government of the People's Republic of Bangladesh, Dhaka, 2018, pp. 290.

11. Marles RJ. Mineral nutrient composition of vegetables, fruits and grains: The context of reports of apparent historical declines. J Food Compost Anal. 2017;56:93-103. https://doi.org/10.1016/ j.jfca.2016.11.012

12. Ülger TG, Songur AN, Çırak O, Çakıroğlu FP. Role of vegetables in human nutrition and disease prevention. In: Asaduzzaman M, Asao T, editors. Vegetables - Importance of Quality Vegetables to Human Health. Intech Open; 2018; https://doi.org/ 10.5772/ intechopen.77038

13. Zulfiqar F, Casadesús A, Brockman H, Munné-Bosche S. An overview of plant-based natural biostimulants for sustainable horticulture with a particular focus on moringa leaf extracts. Plant Sci. 2020;295:110194. https://doi.org/10.1016/j.plantsci.2019.110194

14. Su B and Chen X. Current status and potential of Moringa oleifera leaf as an alternative protein source for animal feeds. Front Vet Sci. 2020;7:53. https://doi.org/ 10.3389/fvets.2020.00053

15. Meireles D, Gomes J, Lopes L. A review of properties, nutritional and pharmaceutical applications of Moringa oleifera: integrative approach on conventional and traditional Asian medicine. Adv Tradit Med. 2020; 20:495-515. https://doi.org/10.1007/s13596-020 -00468-0

16. Venudevan B, Srimathi P, Natarajan N,Vijayakumar RR. Influence of seed fortification treatment with leaf extract on seedling production in bael tree (Aegle marmelos L.). Int J Agric Sci.
2016;12:210-14. https://doi.org/10.15740/HAS/IJAS/12.2/210-214

Damilola AM, Temitope MFO. Assessment of Moringa oleifera as bio-pesticide against Podagrica spp on the growth and yield of okra (Abelmoschus esculentus L. Moench). J Hortic. 2020;7:263. https://doi.org/10.35248/2376-0354.20.07.263

18. Fertilizer Recommendation Guide-2012. Bangladesh Agricultural Research Council, Dhaka, Bangladesh. 2012.

19. Nelson DW, Sommers LW. Determination of total nitrogen in plant material. Agron J. 1973;65:109-12. https://doi.org/10.2134/ agronj1973.00021962006500010033x

20. Piper CS. Soil and plant analysis: a laboratory manual of methods for the examination of soils and the determination of the inorganic constituents of plants. Bombay : Hans Publishers; 1966.

21. Gomez KA, Gomez AA. Statistical Procedures for Agricultural Research. New York: John Wiley \& Sons; 1984.

22. Russel DF. MSTAT-C package programme. Crop and Soil Science, Department, Michigan State University, USA.1986.

23. Emongor V. Effects of moringa (Moringa oleifera) leaf extract on growth, yield and yield components of snap beans (Phaseolus vulgaris). Br J Appl Sci Technol. 2015;6:114-22. https:// doi.org/10.9734/BJAST/2015/14795

24. Anwar F, Latif S, Ashraf M, Gilani AH. Moringa oleifera: A food plant with multiple medicinal uses. Phytother Res. 2007;21:1725. https://doi.org/10.1002/ptr.2023

25. Abdalla MM. The potential of Moringa oleifera extract as a biostimulant in enhancing the growth, biochemical and hormonal contents in rocket (Eruca vesicaria subsp. sativa) plants. Int J Plant Physiol Biochem. 2013;5:42-49. https://doi.org/ 10.5897/ IJPPB2012.026

26. Makkar HPS, Francis G, Becker K. Bioactivity of phytochemicals in some lesser-known plants and their effects and potential applications in livestock and aquaculture production systems. Anim Feed Sci Technol. 2007;1:1371-91. https://doi.org/ 10.1017/ S1751731107000298

27. Mvumi C, Tagwira F, Chiteka AZ. Effect of moringa extracts on growth and yield of maize and common beans. Greener J Agric Sci. 2013;3:55-62. https://doi.org/10.15580/ GJAS.2013.1.111512264

28. Merwad ARMA. Using Moringa oleifera extract as bio-stimulant enhancing the growth, yield and nutrients accumulation of pea plants. J Plant Nutr. 2017;41:425-31. https://doi.org/10.1080/01904167.2017.1384012

29. Busani M, Patrick JM, Arnold H,Voster M. Nutritional characterization of moringa (Moringa oleifera Lam.) leaves. Afr J Biotechnol. 2011;10:12925-33. https://doi.org/ 10.5897/AJB10.1599

30. Yameogo CW, Bengaly MD, Savadogo A, Nikilema PA, Traore SA. Determination of chemical composition and nutritional values of Moringa oleifera leaves. Pak J Nutr. 2011;10:264-68. https:// doi.org/10.3923/pjn.2011.264.268

31. Nasir M, Khan AS, Basra SA, Malik AU. Foliar application of moringa leaf extract, potassium and zinc influence yield and fruit quality of 'Kinnow' mandarin. Sci Hortic. 2016;210:227-35. https://doi.org/10.0.3.248/j.scienta.2016.07.032 